Images In...

\title{
Sigmoid gallstone ileus: a rare cause of large bowel obstruction
}

\author{
NT Ventham, ${ }^{1}$ T Eves, ${ }^{1}$ D Raje, ${ }^{2}$ P Willson ${ }^{2}$ \\ ${ }^{1}$ London Deanery, London, UK \\ ${ }^{2}$ Department of General Surgery, Kingston Hospital, London, UK
}

Correspondence to NT Ventham, n.ventham@hotmail.co.uk

\section{DESCRIPTION}

A 91-year-old woman presented with abdominal distension and pain. She had not vomited and opened her bowels only with scanty stool. On examination she was tachycardic with a distended abdomen with left-sided tenderness. On admission her $C$ reactive protein was $77 \mathrm{mg} / \mathrm{l}$, white cell count of $9.9 \times 10^{9} 1$ and normal liver function tests. Abdominal plain films revealed dilated large bowel. Subsequent CT scan showed aerobilila and a large $4.6 \mathrm{~cm}$ gallstone lodged in the sigmoid colon (figure 1). An attempt at removal by flexible sigmoidoscopy failed. She underwent a limited laparotomy where a successful enterolithotomy was performed (figure 2). She made an uneventful recovery and remains well on 3-months' follow-up.
Gallstone ileus causing obstruction of the sigmoid colon is rare. A cholecystocolonic fistula is the usual mechanism for passage of a large gallstone capable of obstruction into the colon. Of the few cases of sigmoid gallstone ileus in the literature, conservative, endoscopic and surgical management have been advocated. ${ }^{1}$ Endoscopic management includes snaring the stone or using a lithotripter to break up the stone. Surgical options include enterolithotomy (laparoscopic or open) $)^{2}$ or single-stage enterolithotomy with cholecystectomy and fistulectomy with cholangiography if deemed necessary. The latter is technically difficult and should be reserved for low-risk patients. ${ }^{3}$ In the higher-risk population, we advocate an initial attempt at endoscopic

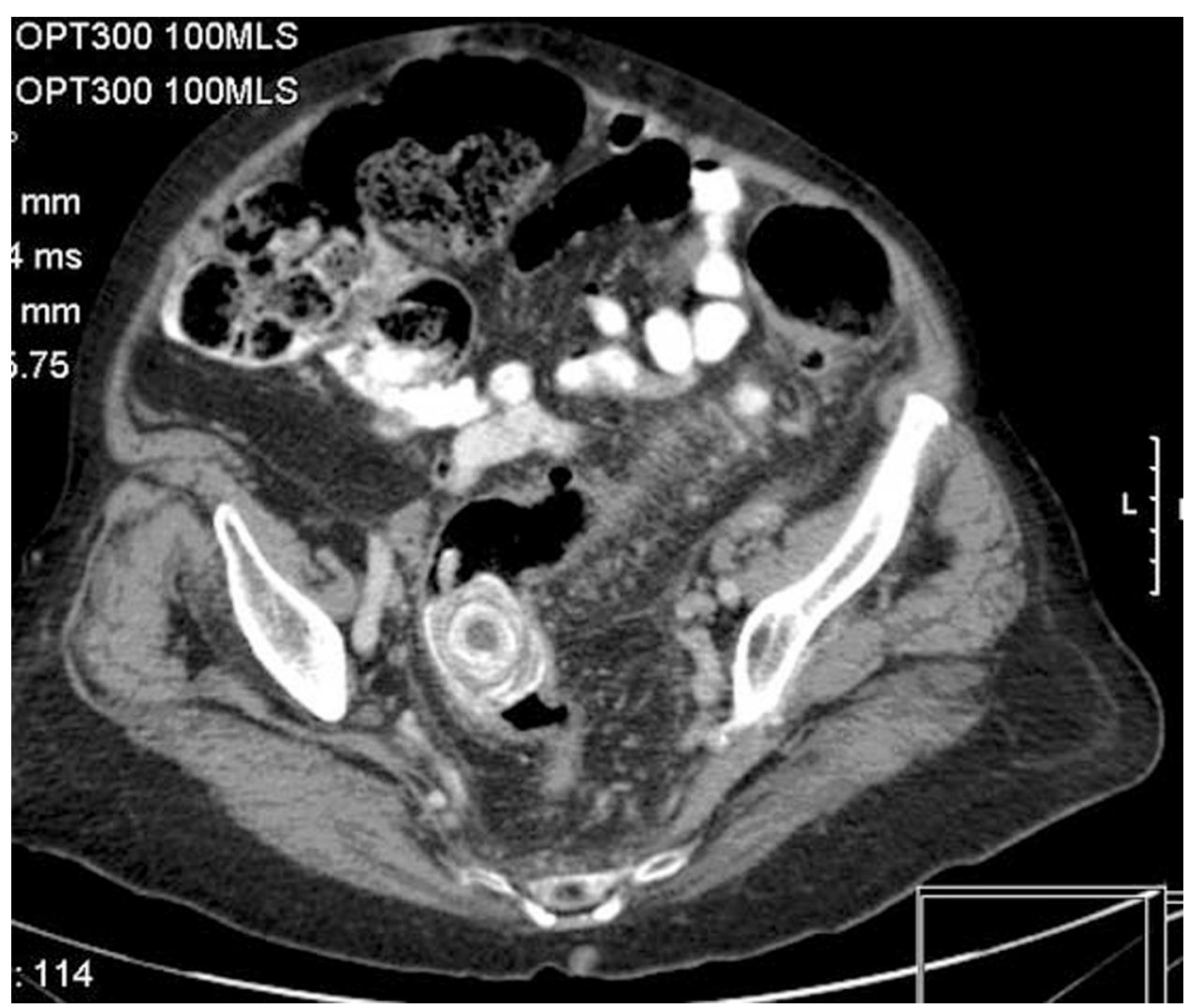

Figure 1 CT scan showing a $4.6 \mathrm{~cm}$ gallstone in sigmoid. 


\section{BMJ Case Reports}

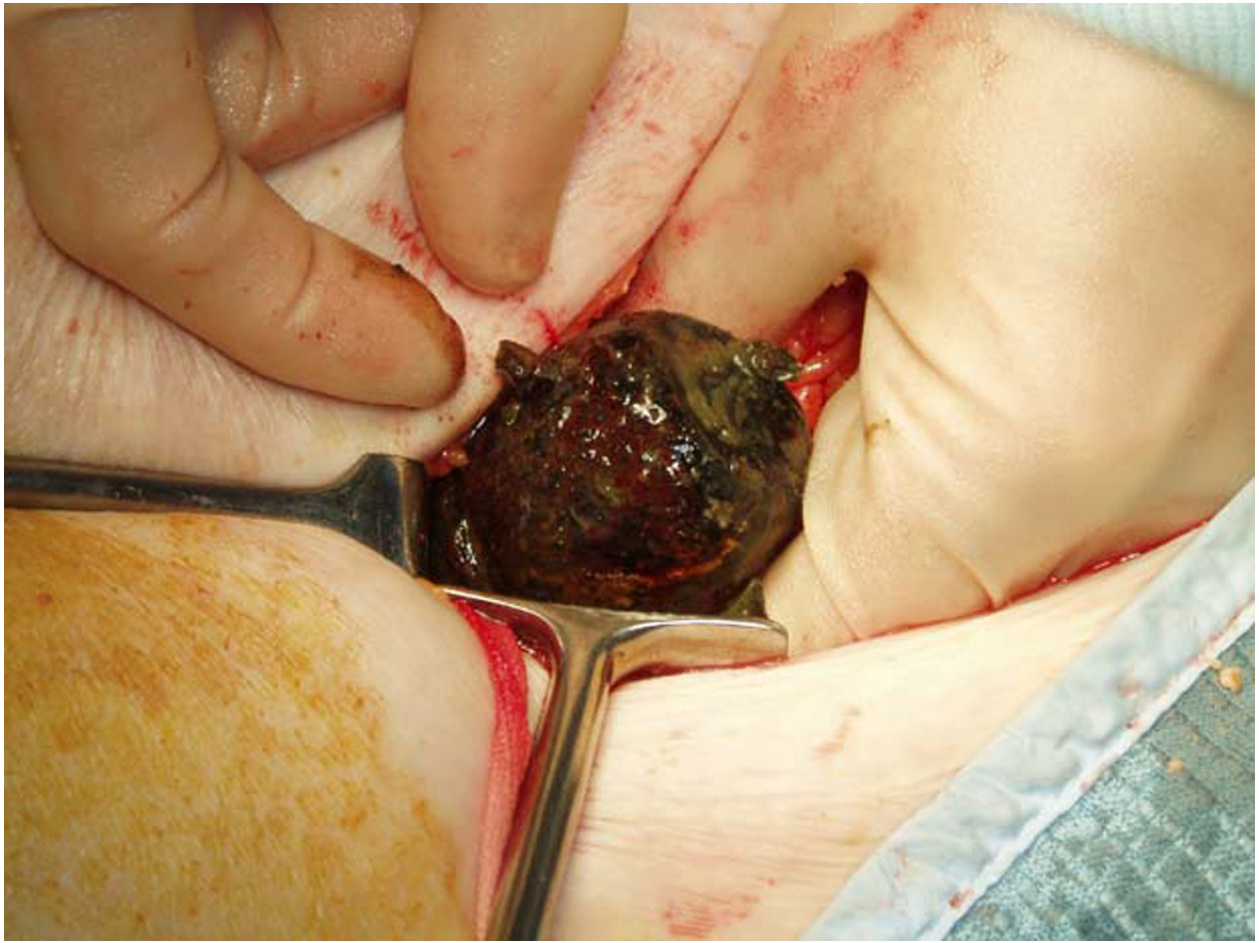

Figure 2 Open enterolithotomy.

removal, which if fails could then be followed-up with an open enterolithotomy. An interval fistulectomy and cholecystectomy could then be performed depending upon patient fitness and choice.

\section{Competing interests None.}

Patient consent Obtained.

\section{REFERENCES}

1. Maltz C, Zimmerman JS, Purow DB. Gallstone impaction in the colon as a result of a biliary-colonic fistula. Gastrointest Endosc 2001;53:776.

2. Mohamed ZK, Balupuri S, Boobis LH. Colonic gallstones: a case report. HBPD INT 2007; 6:324-5.

3. Reisner RM, Cohen JR. Gallstone ileus: A review of 1001 reported cases. Am Surg 1994;60:441-6.

\footnotetext{
This pdf has been created automatically from the final edited text and images.

Copyright 2010 BMJ Publishing Group. All rights reserved. For permission to reuse any of this content visit http://group.bmj.com/group/rights-licensing/permissions.

BMJ Case Report Fellows may re-use this article for personal use and teaching without any further permission.

Please cite this article as follows (you will need to access the article online to obtain the date of publication) of publication

Become a Fellow of BMJ Case Reports today and you can:

- Submit as many cases as you like

- Enjoy fast sympathetic peer review and rapid publication of accepted articles

- Access all the published articles

Re-use any of the published material for personal use and teaching without further permission

For information on Institutional Fellowships contact consortiasales@bmjgroup.com

Visit casereports.bmj.com for more articles like this and to become a Fellow
}

Ventham NT, Eves T, Raje D, Willson P. Sigmoid gallstone ileus: a rare cause of large bowel obstruction. BMJ Case Reports 2010;10.1136/bcr.04.2010.2886, date 